\title{
Primary Research on the Network Marketing of Musical Instrument Galleries
}

\author{
Li-fang Tang \\ Department of Computer Engineering \\ Cangzhou Normal College \\ Cangzhou, Hebei Province, China \\ e-mail :tiandoudou2008@126.com
}

\begin{abstract}
Along with the thriving development of e-commerce and internet-of-things, on-line market economy also expands fast, which totally changes people's consumption behaviors; shopping across regions and group buying are increasingly favored by people. How to make the best use of network becomes a new issue considered by all managers of musical instrument gallery. In this paper, a detailed account is given to the philosophy and strategy of on-line integrated marketing to provide each manager of musical instrument gallery with a good programme for expanding market and seeking new profit growth points through network.
\end{abstract}

Keywords-Musical instrument gallery;on-line integrated marketing; strategy

\section{MUSICAL INSTRUMENTS INDUSTRY AND CONSUMER MARKET; ANALYSIS OF CONSUMERS AND THEIR BUYING HABITS}

\section{A. Musical instruments industry and consumer market}

Along with the continual improvement of people's demands for consumption and cultural life level, the musical instruments industry in China has been developing at an annual growth rate of $10 \sim 15 \%$. At present, there are about 15000 musical instrument galleries and annual value of production of large and medium musical instruments companies is about 24.6 billion yuan;[1] See TABLE I for the number of musical instruments sold in China each year. China has become a large musical instruments manufacturer and seller.

TABLE I.

THE QUANTITY OF SOLD MUSICAL INSTRUMENTS

\begin{tabular}{|l|c|}
\hline \multicolumn{1}{|c|}{ Name of musical instruments } & Quantity of sale (0,000) \\
\hline Piano & 30 \\
\hline Violin & 84.5 \\
\hline Accordion & 19.2 \\
\hline Electronic musical instruments & 107 \\
\hline Western wind instruments & 130 \\
\hline Guitar & 600 \\
\hline Harmonica & 1840 \\
\hline Folk instruments & 500 \\
\hline
\end{tabular}

Musical instruments are gradually accepted by folks in recreation. Musical instruments are no longer exclusive to professionals; naive children, philharmonic young people, white collars hoping to improve their quality, the middle-aged adults hoping to enrich themselves, and the elderly idle at home... all hope to learn music. Therefore, the musical instrument market has walked to the second and third market, becoming a new profit growth point.

\section{B. Analysis of consumers and their buying and consumption habits}

Parents of musical instrument-learning children and the young people who are interested in music are the main consuming power of musical instruments. At present, most parents of musical instrument-learning children are born in 1970s or 1980s. The consumption populations are from 18 to 45 years old; they are prone to accept new things and have higher educational level and strong power of consumption. In buying musical instruments, female are more active. Before buying, they usually consult the parents whose child have learned such instrument or listen to teacher's recommendations. Besides, parents of musical instrument-learning children can also surf the internet to search and look through information about the musical instruments products and brands. Open the page of Baidu, you can find the frequent search keywords: brands of musical instruments, musical instruments-top ten famous brands of musical instruments, top ten famous musical instruments brands of China, top ten musical instruments brands etc. [2]

While choosing musical instruments, consumers usually consider the following factors: popularity and reputation of the brand; popularity of the musical instrument gallery and quality of the musical instruments; price and discount policies of instruments; after services provided by the manufacturer; recommendation and promotion by the instrument seller; consumer's aesthetic appreciation and functional demands; opinions from surrounding acquaintances and the network; recommendation by training courses etc.

According to the consumption level, the consumer group can be divided into high-end one and medium and low-end one. For high-end consumers, brand is the first thing to be considered; Medium and low-end consumers pay more attention to quality and price. The medium consumers who have certain purchasing power and at the same time pursue high quality of life (including white collars and civil servants) pay more attention to product quality and after services while purchasing musical instruments. 


\section{Usual Marketing Policies ANd PREsent Status of MUSICAL INSTRUMENTS}

\section{A. Traditional brand popularization and market popularization channels}

First, confirm that you have the correct template for your paper size. This template has been tailored for output on the A4 paper size. If you are using US letter-sized paper, please close this file and download the file for "MSW US ltr format".

- Off-life popularization channels include: television advertising, broadcasting, performance sponsorship, newspaper, billboards, posters etc.

- On-line popularization channels: build instruments website to propagandize products; place advertisements in news, on education forum, website of schools, website of life and shopping etc.

\section{B. Usual marketing policies}

Brand strategy: improve brand awareness through placing advertisements, exhibitions of products, campus popularization, public performance etc., including outdoor advertisements, paper media advertisements and advertisements on professional musical instruments website.

Channel strategy: develop provincial and municipal experiential speciality stores and franchise stores at county levels to form an integral marketing channel net through meetings for invitation of business investment, interviews, discussions etc.

Popularization of new products: to popularize new products through national and regional musical instruments promotion fairs, public performance, community activities, media reports etc.

\section{Present marketing status of musical instruments}

1) Shortage of music talents restricts musical instrument galleries from being larger and stronger. Besides the selling and buying of musical instruments, musical instrument galleries are also responsible for after-sales repair of musical instruments, music education and cultural transmission. This requires the managers to have both musical and cultural literacy, and certain economic power. Students majored in music would like to stay in first-tier cities instead of working in second and third tier market. As a result, musical instrument galleries concentrate in first-tier cities and profits there decline; By contrast, although there are great demands in the second and third tier cities, there are few people develop the market there, which prevents the musical instruments market from be larger and stronger.

2) Advertisements cost a lot but harvest little. Broadcasting of the highly costing advertisements does not improve the brand awareness greatly. Most advertisements are even unknown and can't achieve the expected communication effects and companies may take great risks in doing so.
3) Public performance may not have a continual effect. It may sensational at a moment like a flash in the pan, but its tramsmission scope and influence is small.

4) Competition from the fellow traders is severe and sales profits of musical instruments are low. Dealers of musical instruments may choose to survive through price competition, so they can't obtain fair profits. They may also sell musical instruments of unknown brands to get high profits, which pays no attention to longterm interest and damages their own image.

5) Internet becomes a channel for consumers to get product information and buy products. On-line shopping has walked to people's daily life: if you want group buying, choose Juhuasuan; if you want to buy books, choose Dangdang; if you want to buy electric appliances, choose Jingdong; if you wang to buy brand products, choose Vipshop. According to relevant statistics, one-day sales amount of Taobao equals to one-year sales amount of Wangfujing.

6) With the thriving development of internet-of-things and e-commerce, the big market for musical instrument distribution has formed. In June 2010, the first experiential musical instruments shop MUSICVOX started business. With about $700 \mathrm{~m} 2$ open shopping place, 3500 musical instruments, it presents the most accessible and fashionable music life. Taobao, Amazon China and Jingdong all thread their way and start on-line shopping of musical instruments; their products include guitar, digital piano, national musical instruments, violin, musical instrument assemblies etc. and most brands are medium-low end ones. It shows that internet has stimulated the formation of a large musical instrument market and the distribution market enters to a high speed development age.

\section{ON-LINE INTEGRATED MARKETING STRATEGY OF MUSICAL INSTRUMENT GALLERIES}

Network economy advances irresistibly; it has been a new issue for each manager of musical instrument gallery to promote the sale of musicial instruments and create profits. The use of on-line integrated marketing can help to spread the popularity of musical instrument galleries on line comprehensively from all aspects and stimulate product sales and create new profit growth points continuously.[3]

\section{A. The concept of on-line integrated marketing}

On-line integrated marketing means within a certain period of time, selling institutions restructure corporate and market behaviors with consumers as the core, integrate and coordinate different transmission modes with internet as the main channel to transmit continual and consistent corporate or product information with uniform objectives and images and realize the two-way communications between consumers, in the hope of building brand image as soon as possible, establishing a long term close relationship between products and consumers, and realizing brand communication and product selling more effectively.

Core philosophy of on-line integrated marketing is to: centralize all transmission activities relating to companies' marketing activity. Specifically speaking, it aims to integrate 
on-line brand advertisements, search engine marketing, blog marketing, focus marketing, email marketing, and animation marketing strategies into brand communication and product market popularization and business investment popularization plan and add new marketing elements including news marketing, interactive marketing, community marketing, word of mouth marketing etc. to achieve the buzz effect of marketing communication.

\section{B. Feava marketing policy of musical instrument galleries}

It takes the initials of five words, namely Focus, Event, Activity, Video and Animation, which also consititutes five marketing modes, namely, focus marketing, event marketing, activity marketing, on-line video advertising marketing and animation marketing.

\section{1) Focus marketing}

It takes the initials of five words, namely Focus, Event, Activity, Video and Animation, which also consititutes five marketing modes, namely, focus marketing, event marketing, activity marketing, on-line video advertising marketing and animation marketing.

QQ groups, blogs and MSN groups...among these groups, those born in the 1980s and 1990s take pleasure in sharing their own experience and would kindly take other's recommendations to be their own criteria for consumption. Musical instrument galleries can build a consumer group and invite a great many consumers to share promotion information or release information about new products in the group to stimulate consumption through focus marketing. [4]

\section{2) Event marketing}

Consumers usually focus their attentions on the things that they are interested in, so network marketing of musical instruments mush cater to their interest and concentrate on the topics and events that they are interested in to bring about a series of comments, description and stories centering those topics or events to excite wide resonance effects to improve brands and promote distribution.

\section{3) Activity marketing}

- Open expert blog and company official website. Through blogs, relevant questions about music can be answered on line and through the official website, information about products can be released. These two are from the aspect of company and leisure respectively and can recommend and complement each other while answering net-surfers' questions and can form favorable interactive effects.

- Compose news release. Increase the exposure rate of the musical instrument gallery and improve its brand awareness through issuance on general news platform and republishment through forums and blogs.

- $\quad$ Set up music libraries. Enrich the relevant knowledge of music, answer special questions about music to improve the musical instrument gallery's reputation so as to realize word of mouth marketing.
- Conduct on-line awarded musical instruments knowledge guessing. Enhance net-surfers' awareness of participation and improve consumers' loyalty index.

- Make charge-free electronic music books for children, and realize viral marketing through the sharing and propaganda of e-books.

\section{4) On-line video advertisements}

Video advertisement combines TV short films with internet. It can show the contents vividly and precisely and at the same time spread information widely on line. With the continual integration of three networks, on-line video shorts are gradually accepted by trainditional TV terminals, mobiles and other mobile terminals. They are showing great powers and become an increasingly important link in integrated marketing. We can upload the tie-up films to Tudou, Sohoo HD, and pplive for effective propaganda.

\section{5) Animation marketing}

Animations can attract people's attention with very kind and humanistic features. At the same time, they can also show the company's features, build corporate image, and shorten the gap between companies and consumers. The application of animations in corporate marketing is known as animation marketing. We can spread well designed animation works through QQ expressions, caricatures, flashMTV, and brand theme animation images to show the brand image and tell stories about the brand, and convey the philosophy of the brand's affinity, juvenility and vogue.[5] The transmission of thousands of times through the network can help to improve the brand awareness and brand image fast.

\section{ON-LINE INTEGRATED MARKETING COMMUNICATION SOLUTIONS OF MUSICAL INSTRUMENT GALLERIES}

\section{A. What to sell?}

In network marketing, main consumers are the parents of musical instrument-learning children and the young that are interested in music. They are about 18 -45 years old and have certain purchasing power. We can sell low-cost small musical instruments and assemblies through network and sell large and professional musical instruments in real shops. In doing so, we don't need a real shop covering thousands of $\mathrm{m} 2$; we only need to place some large and excellent musical instruments so as to reduce the rents of shop, and the saved funds can be used to buy more goods. Low price distribution through the network can speed up withdrawl of funds. Intangible goods such as services, software, and music can be sold through network directly. [6]

\section{B. How much do musical instruments cost?}

Due to the transparent product price on the internet, competitions between enterprises are severer. Take advantage of the interactive strengths of network and make prices centering on consumers; provide flexible price list and instrument directory for consumers to choose and purchase and sell goods after the instruments and price are accepted by consumers. In doing so, we can avoid making too high or too low price without understanding the market demands. 


\section{Where to build the on-line shops of musical instrument galleries?}

Taobao shopping mall is the best choice. Taobao has a large consumer group and popularity, safe ordering system, and fast search sysem, enabling consumers to purchase products safely and fast; Alipay payment system can help to manage funds fast and conveniently; On-line message and demand submission are convenient for the real-time communication between sellers and consumers and can improve the marketing efficiency. Convenient cooperation with logistics companies can realize the efficient delivery and warehousing of products.

\section{Marketing of musical instrument galleries forms scales on line and increases sales volume off line.}

FEAVA marketing can maintain the persistance of sensational effects and promotion effects. It won't conflict with the existing pricing structure, and can help off line dealers to improve the bargaining power with end users, achieving two aims at the same time; Besides, it can also faciliate the fast distribution in off line channels and finally promote selling through persistent promotion.

\section{E. Choose special marketing teams.}

Special marketing teams can ensure the originality level, execution efficiency, marketing persistence and success rate. What the musical instrument gallery shall do is to ensure the selection of appropriate institutions, selection of programs, determination of cooperation contents, monitor and assessment of the implementation process.

\section{EFFECTS OF INTEGRATED NETWORK MARKETING OF MUSICAL INSTRUMENT GALLERIES}

- Fast promotion of brand awareness and cognitive strength of musical instruments;

- Expand consumer groups and strengthen young people's identification to brand and awareness of consumption;

- Recreational and fashionable marketing communication mode through animation and video can make the brand younger and more energetic; besies, it can also help to keep the favorable communication with potential consumers and improve the degree of identification to brand culture;

- It can pave a way for local brands to step into the national market and obtain preemption of marketing through low cost and highly yielding on-line integration transmission;

- $\quad$ Establish or expand the company's network marketing channels and improve the sales volume and profit margin of retailing and group buying.

\section{CONCLUSION}

On-line shops have the strengthes over low cost an flexible turnover of capital, but many manufacturers do not favor online distribution. The main reason is that network is limiting to the musical instruments that stress on the quality of sound. Besides, on-line musical instrument shops have both high quality ones and low quality ones, and they can't provide proper professional after services or track the follow up training. On-line distribution comes irresistibly. A good way for musical instrument galleries to walk to a new era is to combine the real shops and integrated network distribution effectively.

\section{REFERENCES}

[1] Huang Wei, Marketing of Musical industry Galleries is expansing ,who pays? in Musical Instrument, pp. 92-95,Nov 2009. (In Chinese)

[2] Huang Wei, Chinese Musical industry into the " high-speed rail ", the Internet of big market concept formation in Musical Instrument, pp. 9697,Nov 2010. (In Chinese)

[3] Liu hui-fen,Zhou qing-qing, Research on customer-centered EIMC mode in Journal of Nanjing University of Posts and Telecommunications (Social Science) pp.11-14, Sep.2011(In Chinese)

[4] Luo Jianhua and Chen Jianke, Research on Data Mining Application in Tourism E-Commerce,in E-Business Journal, pp. 28-32, August 2011 (In Chinese)

[5] Zhao Lifen, Research on Application of Data Mining Technology in ECommerce, Applied Technology of Computer Engineering, pp. 174, April 2011 (In Chinese) (references)J. Clerk Maxwell, A Treatise on Electricity and Magnetism, 3rd ed., vol. 2. Oxford: Clarendon, 1892, pp.68-73. (In Chinese) (references)

[6] Chen Wei, The Application of Data Mining Technology in Digital Product Sales Business in Computer Knowledge and Technology,Vol.6,NO.2,January 2010,pp.273-274,280. (In Chinese) (references) 